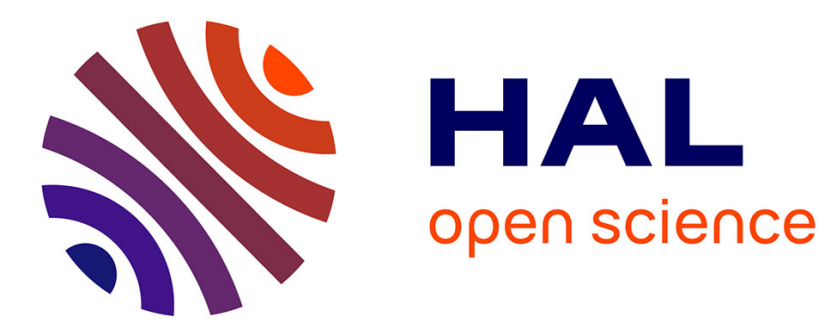

\title{
Remote Sensing of Environmental Change in the Antirio Deltaic Fan Region, Western Greece
}

Emmanuel Vassilakis

\section{To cite this version:}

Emmanuel Vassilakis. Remote Sensing of Environmental Change in the Antirio Deltaic Fan Region, Western Greece. Remote Sensing, 2010, 56, pp.128 - 2560. 10.5589/m06-019 . hal-01519622

\section{HAL Id: hal-01519622 \\ https://hal.science/hal-01519622}

Submitted on 8 May 2017

HAL is a multi-disciplinary open access archive for the deposit and dissemination of scientific research documents, whether they are published or not. The documents may come from teaching and research institutions in France or abroad, or from public or private research centers.
L'archive ouverte pluridisciplinaire HAL, est destinée au dépôt et à la diffusion de documents scientifiques de niveau recherche, publiés ou non, émanant des établissements d'enseignement et de recherche français ou étrangers, des laboratoires publics ou privés. 
Article

\title{
Remote Sensing of Environmental Change in the Antirio Deltaic Fan Region, Western Greece
}

\section{Emmanuel Vassilakis}

Department of Dynamics, Tectonics and Applied Geology, Faculty of Geology \& Geoenvironment, National \& Kapodistrian University of Athens, Panepistimioupoli Zografou, 15784, Athens, Greece; E-Mail: evasilak@geol.uoa.gr; Tel.: +30-210-727-4869; Fax: +30-210-727-4096

Received: 30 August 2010; in revised form: 26 September 2010 / Accepted: 9 November 2010 / Published: 16 November 2010

\begin{abstract}
In the westernmost region of the rapidly widening Corinth rift, Greece, extensive development of roads, bridges and other human infrastructure has caused continuous environmental change over the past twenty years. River networks, the land surface and the coastal environment, have been altered, especially in the areas corresponding to deltaic fans. In this paper we use earth observation systems that have captured these environmental changes, particularly medium (Landsat TM and ETM+) and high (Quickbird) resolution satellite images, to identify environmental changes between the periods 1992, 2000, 2002, and 2005. Six pseudo-color multi-temporal images in different spectral areas were created in order to detect changes to the terrestrial and coastal environment caused mainly by direct or indirect human impact. This methodology provided new data for quantifying significant alterations in the environment on different scales. In many cases this revealed their sequence during the time of observation.
\end{abstract}

Keywords: Multi-temporal image processing; change detection; Landsat; Enhanced Thematic Mapper; Quickbird; Gulf of Corinth; Antirio Bridge

\section{Introduction}

Over the last two decades the Greek government has proceeded with infrastructure development within the western part of Greece. Formerly there was no uninterrupted highway that connected mainland Greece in the north with the Peloponnesus in the south, and the Gulf of Corinth interrupted the land continuity. Until recently, the only direct modern road connecting these large parts of the country was on the easternmost side of the gulf where the natural strait is located. Transportation 
across the western part of the gulf consisted of small ferries completing the route between Rio (mainland Greece) and Antirio (Peloponnesus). This distance, of not longer than two kilometers, was covered by a ferry in about 15 minutes, not including the time for embarkation and disembarkation, but only during adequate weather conditions.

The Gulf of Corinth is one of the most rapidly spreading rifts in the world, generating large and disastrous earthquakes [1-5]. Thus, one of the main arguments against construction of a bridge across the gulf was the high seismic potential of the area, which is related to its rapid expansion, determined by GPS techniques to be an average of $18 \pm 2 \mathrm{~mm} / \mathrm{yr}$ in an approximately north-south direction across the gulf [6-9]. New construction techniques allowed for design of the Rio-Antirio Bridge, which was structurally supported by different fault blocks. Its design allowed the bridge to remain intact during future differential movements of the fault blocks [10]. The bridge was finally completed in 2004, providing a modern alternative highway along the western part of Greece.

The anticipated increase in traffic along the highways leading to the bridge encouraged the local authorities to extend and widen the existing road network to the north-east and the west, and especially north of the bridge in the mainland sector. Accordingly, several construction sites were developed in the area surrounding the Antirio deltaic fan (Figure 1). Some of these are still ongoing as planned (quarries, highways, junctions, tunnels, etc.) and a high quality highway will be completed during the next decade, providing easier, safer and faster transportation in western Greece.

Figure 1. The study area on a natural color $(3,2,1-\mathrm{R}, \mathrm{G}, \mathrm{B})$ reference image acquired by Landsat 5 on September 2, 1992. The Quickbird image used in this study $(1,4,3-\mathrm{R}, \mathrm{G}, \mathrm{B})$ is shown as a partially overlapping layer. The white rectangle in the inset shows the location of the study area.

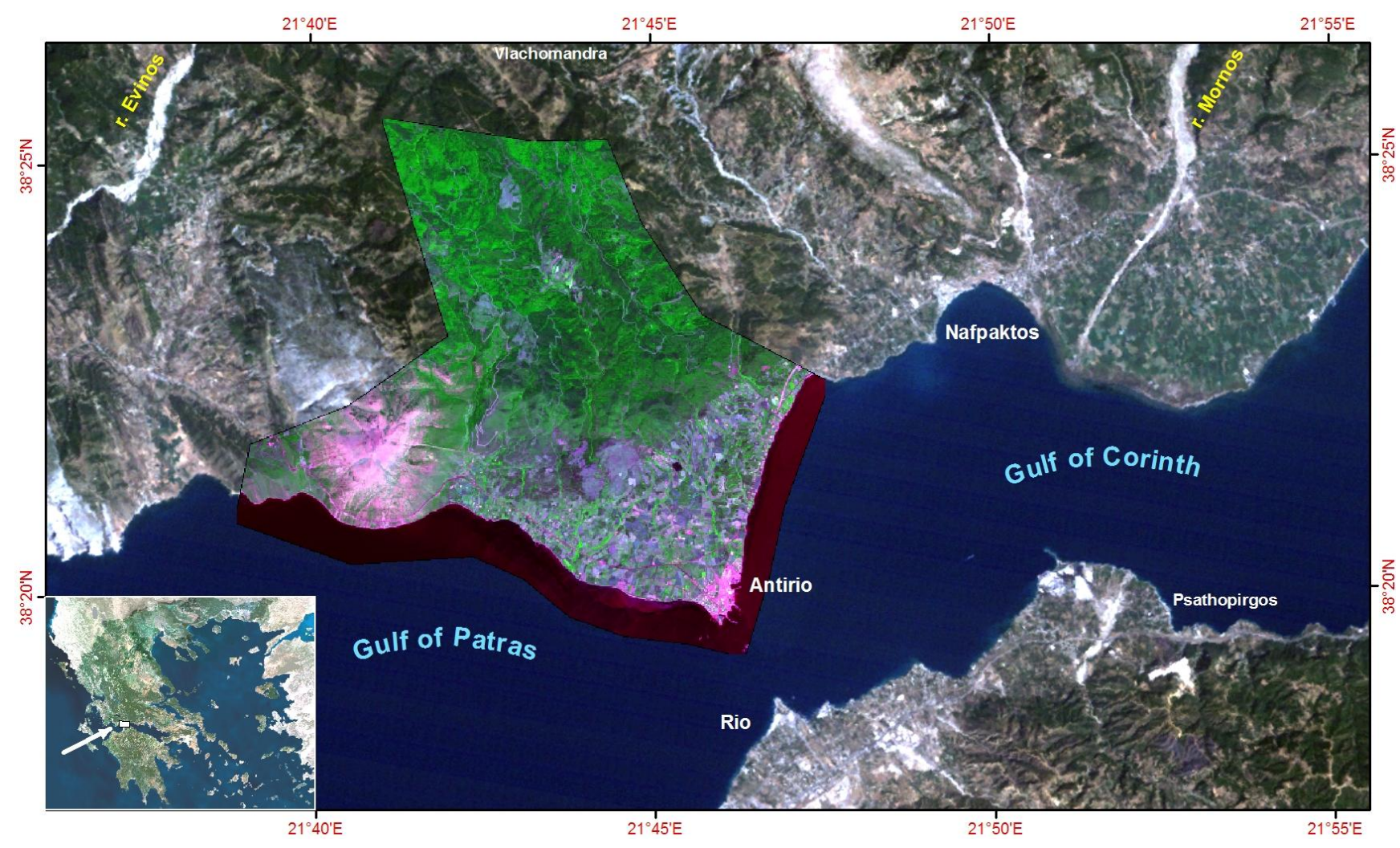


In addition to these sites supporting new highway construction, a new river dam was created to supply fresh water to the eastern part of mainland Greece from the mountainous and densely forested area of western Greece where precipitation is much higher. The dam was constructed on the Evinos River beginning in 1992 and was completed in June 2001. It was filled in October 2002. Water from this dam flows through an artificial tunnel to an older dam (on the Mornos River), before it reaches the network that supplies water to Athens and the surrounding cities. Therefore, in the valley downstream from the dam on the Evinos River, there has been a reduction in the average volume of water that reaches the coastal area just west of the new Rio-Antirio Bridge, along with a reduction in the sediment load carried by the river. Moreover, in the forested area between the Evinos valley and Antirio deltaic fan many wildfires - whether set intentionally or naturally occurring - have occurred over the last several decades. This has had serious consequences for the natural environment because most of the fire damage has not been repaired. Due to the high precipitation in this area, high rates of erosion have been recorded during wintertime, resulting in a large amount of transported material being deposited in a violent way along the Antirio deltaic coastal area [11,12].

This paper concerns the results of a first effort to document the surface changes of this tectonically and geomorphologically active region and to categorize them systematically, for further interpretation. The initial idea was to define whether the changes detected on the earth's surface are caused by the natural procedures of the evolving landscape or due to human interference, or both. The most efficient way to observe environmental alterations on such a wide scale, is the use of various remote sensing data, especially medium to high resolution and in the next section the methodology is described in detail.

\section{Data Processing and Analysis}

In order to detect environmental changes and the implications caused by the large construction sites along the Antirio fan and surrounding areas, several series of earth observation datasets were created. The satellite images used for this purpose were captured during several time periods beginning in 1992 and ending in 2005, and covering most of the area that was affected by the development of new infrastructure, as described in the introduction. The satellite image processing employed in this study includes atmospheric corrections, co-registration of images and creation of multi-temporal data constructed by creating new datasets for every spectral channel. The resulting false color composites reveal environmental changes not only where the construction sites are located but also in the coastal areas where erosion and deposition occur. The higher resolution images were used to increase the spatial resolution of the color composites, accomplished by merging high resolution images with lower resolution images $[13,14]$ for better evaluation and quantification of the environmental alterations.

The first scene was acquired by the Thematic Mapper sensor (TM), placed on board the Landsat 5 satellite, on September 2, 1992, and consists of path 184 and row 33. Processing begins with geometric ortho-rectification in Universal Transverse Mercator (UTM) projection (zone 34N) by including, in the correction procedure, a highly detailed DEM with 25 meters pixel size [15]. The latter was produced by digitizing topographic map contours at a scale of 1:50,000. Subsequently, a dataset with 1123 columns and 577 rows was created; this covered only a part of the total scene and corresponds to the study area. The same procedure and dimensions were also applied to two other datasets, one 
derived from a Landsat 7-ETM+ (Enhanced Thematic Mapper) acquired on June 28, 2000 and another from a Landsat 7-ETM+ acquisition on August 13, 2005. All Landsat data were downloaded from U.S. Geological Survey (USGS) Earth Resources Observation and Science (EROS) Center. The last two datasets were ortho-rectified by using the image to image methodology and taking as reference dataset, the oldest one having the same DEM for altitude reference. A high resolution Quickbird 2 image acquired on June 12, 2002 and covering the central part of the study area was also used for larger scale observations with the highest possible accuracy and was imported in a geodatabase for further study along with the other data. These data were ortho-rectified, pan-sharpened and registered to the Landsat 5 ortho-corrected dataset, which was used primarily as the referencing image (Figure 1). The co-registration procedure of all datasets was successful since the RMS error was calculated less than 0.5 pixels either in $\mathrm{X}$ or $\mathrm{Y}$ geographic axis.

Effects of the atmosphere on remotely sensed data are not considered "errors" because they are part of the signal received by the sensing device. However, it is very important to remove atmospheric effects, especially on visible channels, as it has been noted that the atmospheric contribution to the radiance received by a satellite forms a much greater percentage of the radiance leaving the target area, than in the case of infrared [16]. Because this study is focused on detecting changes in a specific region through time, the main analytical tool relies on ground measurements made over time. Therefore it is very important to correct the radiance values recorded by the sensor for the effects of the atmosphere [17]. The technique that was applied on the Landsat series of datasets was based on the minimum digital number of the middle infrared band 7 for each dataset [18].

In general, when images contain areas of low reflectance, such as clear water bodies and deep shadows caused by extreme relief discontinuities, the corresponding pixels have values very close to zero, especially in the middle infrared band 7 of the Landsat TM and ETM+ sensors. Considering that a water body has virtually no reflection, even at shorter wavelengths such as band 4 or band 5 , the digital number of a pixel representing deep sea water in band 7 should not be significantly larger than zero [19]. If it is larger than zero, then the non-zero digital number is due to atmospheric effects. This enables one to identify the effects of the atmosphere over large water bodies. The existence of the large water bodies in the Gulf of Patras west of the study area, and the Gulf of Corinth east of the study area, are thus very useful for calculating atmospheric corrections. After computing the statistics over each band of every dataset, the histogram minimum value for band 7 was calculated. This value was subtracted from the digital number arrays of the other bands of the same dataset and the result was a new array with digital numbers shifted towards the zero value, and presumably representing data with atmospheric corrections. The statistics for every single band were updated and the histograms were saved.

\section{Multi-Temporal Interpretation}

The acquisition dates of the three Landsat images used for the multi-temporal interpretation were almost ideal for the purpose of this study because nearly all of them were captured during the summertime (late June to early September) when the local weather conditions are similar.

The multi-temporal analysis procedure begins with the compilation of six datasets, each one containing a single spectral channel from the three Landsat images. Each of these datasets contains 
three bands with the same Landsat spectral channel for each acquisition date. The thermal infrared channels of the Landsat 5 and Landsat 7 were not used because the spatial resolution varies for the TM and ETM+ sensors and the thermal reflectance cannot be considered identical throughout long time periods. Thus, the interpretation continues separately for each spectral channel in order to detect changes in the absorption and reflection spectra for specific bandwidths. Subsequently, six pseudo-chromatic images were produced by using the earliest data in the red channel (R-1992), the latest data in the blue channel (B-2005) and the intermediate data in the green channel (G-2000).

The resultant color composite images for every channel are presented in such a way as to locate the areas with high pixel values for each of the red, green or blue colors. In these cases, the earth's surface changed significantly from one acquisition date to the next. These observations proved to be quite difficult to obtain from images collected during the intermediate observation period (2000), as restoration works for the altered land coverage (river flow, forest fire, quarry operations etc.) could have taken place before the capturing date of the last satellite image (2005).

In detail, areas colored nearly pure red in the pseudo-chromatic images reveal areas that suffered significant change after September 2, 1992 and remained unchanged until August 13, 2005. The almost pure green areas represent changes on the earth's surface which happened in the time window between November 3, 1992 and June 28, 2000; with the provision that before and after these dates the land coverage should be more or less similar, or at least the spectral attitude of the area should be the same. If full and successful environmental restorations of an altered area have occurred, these areas would appear as green in each of the six datasets. Otherwise the restoration could not be characterized as completely successful, because the spectral attitude of the rehabilitated area is not the same before and after the environmental alteration. Finally, nearly pure blue areas represent change that happened after June 28, 2000 and before August 13, 2005.

\section{Change Detection Results}

In the pseudo-color image produced from band 1, the most spectacular change is represented by a blue linear feature connecting mainland Greece to the Peloponnesus; this is the Rio-Antirio cable bridge completed in 2004 and inaugurated just before the Athens Olympic Games (Figure 2). The blue color indicates that this bridge did not exist when the first two satellite images were acquired but did exist when the third satellite image was acquired. Thus it is clearly depicted on the 2005 Landsat image, which has been assigned to the blue channel. Its structural towers can be clearly seen in the southern part of the Quickbird image, which was captured before 2004 and apparently during construction (Figure 1). Additionally, the new road junctions on both sides of the gulf next to the bridge are also blue.

In the same image, just northeast of the town of Nafpaktos, a number of blue linear features indicate parts of the new highway detour designed to minimize traffic increase in the town itself. North of Nafpaktos, the lighter blue features with reddish parts are probably several road widenings with roadside banks constructed before 2005 (blue) or trenches constructed after 1992 (red). A new road constructed after 2000 in the forested area $\left(21^{\circ} 43^{\prime} \mathrm{E}, 38^{\circ} 26^{\prime} \mathrm{N}\right)$ is also visible as a blue polyline feature (Figure 2). 
Figure 2. Multi-temporal pseudo-color image produced from layer stacking of Landsat satellite data (Band 1, 0.45 to $0.52 \mu \mathrm{m}$ ) with three different acquisition dates. The diachronic changes in onshore and offshore areas, largely due to infrastructure development after 2000, are clearly shown as blue linear features. The black arrows point to alterations of the surface described in the text. Below, two single band-1 enlargements of the black rectangle area show the changes caused by the bridge construction during the period from 1992 (left) to 2005 (right).

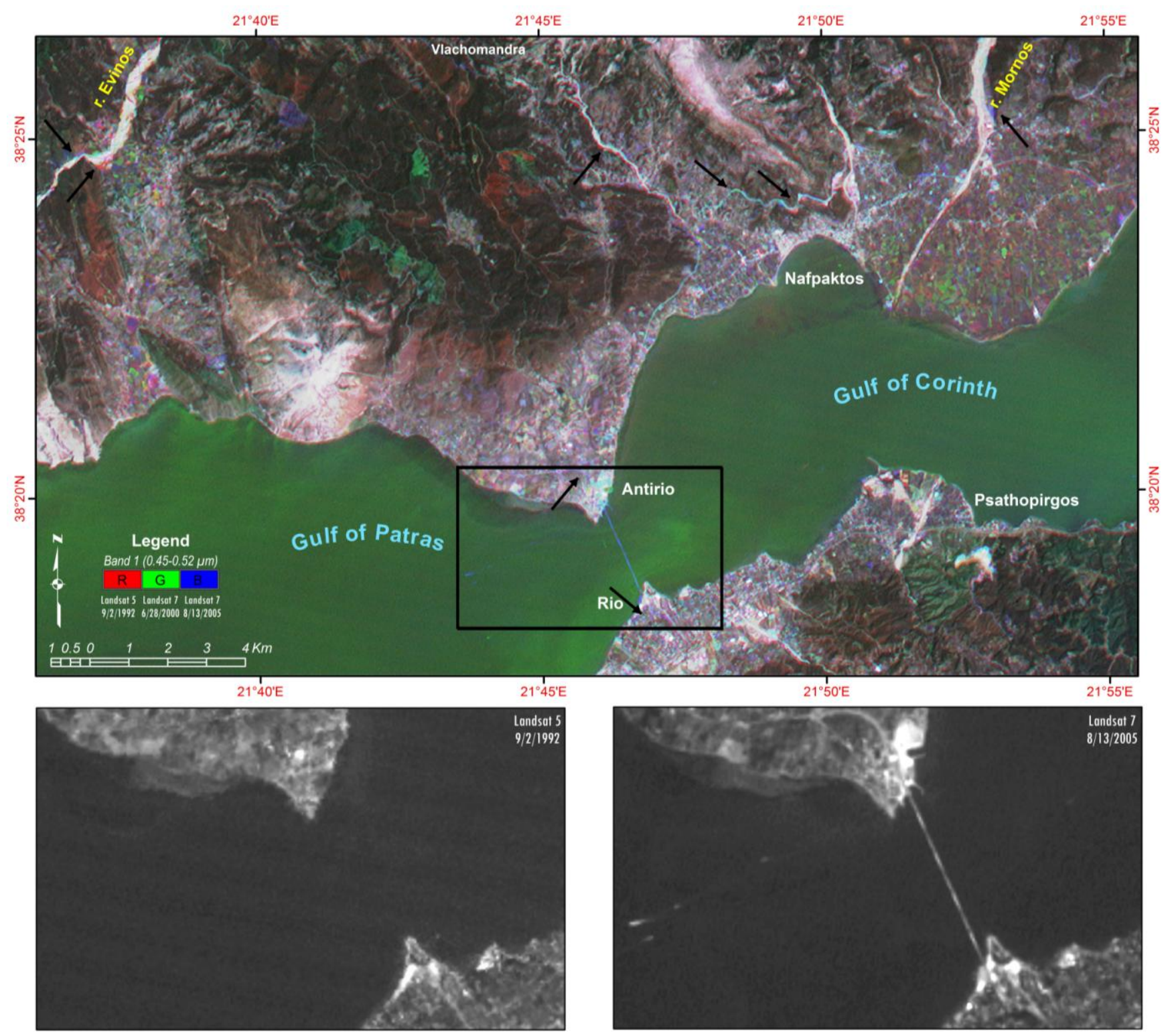

The flysch rocktype that makes up most of the bedrock in the study area has great potential for generating large-scale landslides. Frequent heavy rainfall in this area, combined with surface denudation from road construction and river erosion, cause major and minor land movements, which expose bare soil prior to rehabilitation and the renewal of vegetation (Figure 3). Such phenomena can be identified along the road that connects Nafpaktos with Vlachomandra, especially along the western side of the road where red pixels indicate landslides that happened shortly before 1992 and that were successfully restored before 2000. Larger-scale land movements seem to have occurred before 2005 on 
the eastern bank of the Mornos river $\left(21^{\circ} 53^{\prime} \mathrm{E}, 38^{\circ} 25^{\prime} \mathrm{N}\right)$ and smaller scale changes along both banks of the Evinos river, especially when flysch lithologies were exposed along the river $\left(21^{\circ} 36^{\prime} \mathrm{E}, 38^{\circ} 25^{\prime} \mathrm{N}\right)$.

Figure 3. Multi-temporal pseudo-color image produced from layer stacking of Landsat satellite data (Band 2, 0.52 to $0.60 \mu \mathrm{m}$ ) with three different acquisition dates. Land surface destruction due to mass landsliding along roads and river banks, as well as other changes in bare soil and vegetation, can be identified. The black arrows point to alterations of the surface described in the text.

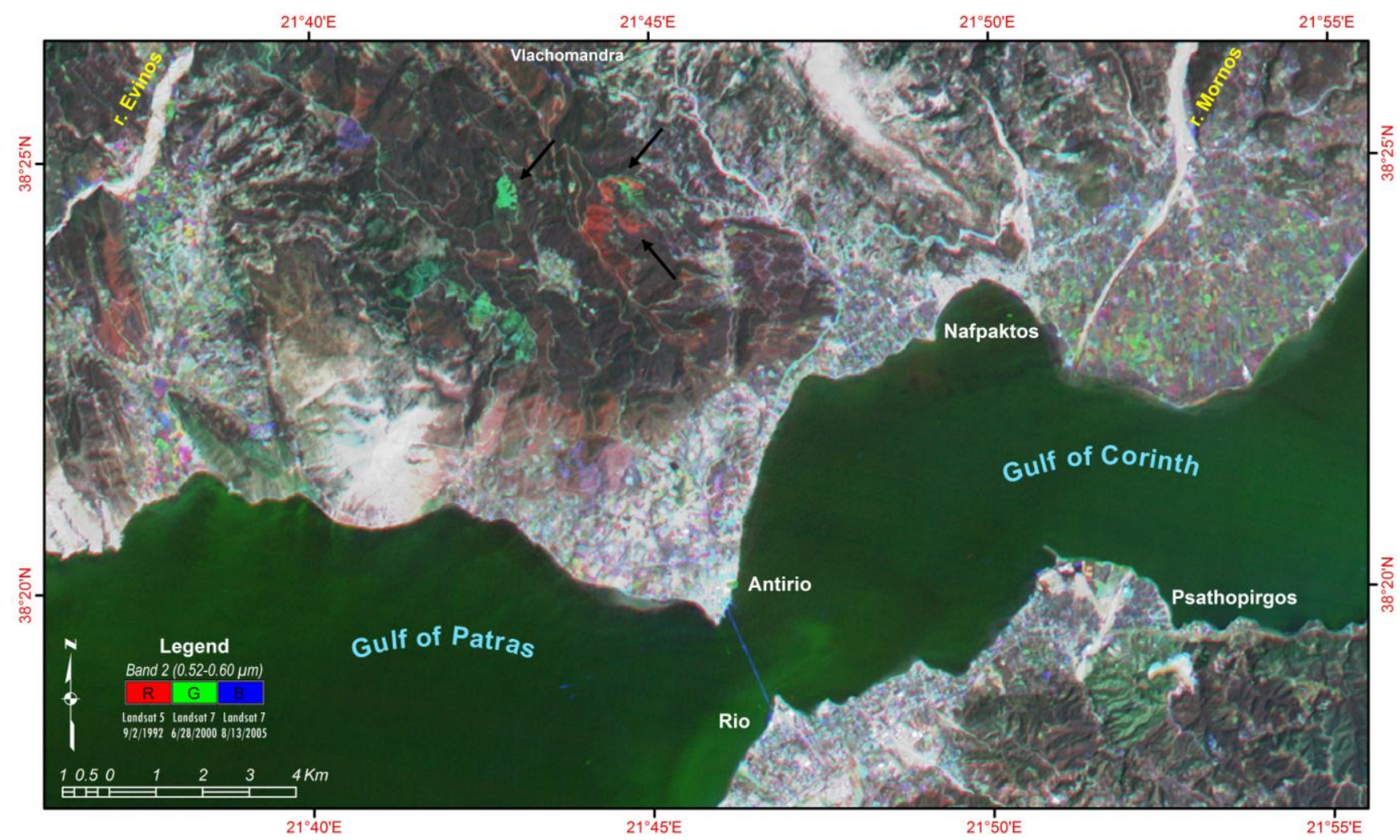

A spectacular change in the land surface resulting from restoration of a burnt area can be observed over a large area in the north central portion of the study area $\left(21^{\circ} 44^{\prime} \mathrm{E}, 38^{\circ} 24^{\prime} \mathrm{N}\right)$. In the oldest image (1992), this large area represents a region of bare soil in the middle of forest-type vegetation; such features normally correspond to tree destruction. In the multi-temporal pseudo-color images this area is colored reddish, whereas a smaller area in between the large ones is colored green (Figures 3,4). In the high resolution Quickbird image (Figure 1) it is clear that in the same area there is a densely vegetated area with striped cultivation corresponding to vineyards. This interpretation is based on the reflectance contrast between bare soil and vegetation. Thus bare soil existed during 1992, a large part of which was cultivated before 2000 (red) and the vineyard expanded between 2000 and 2003 (green); as seen in the Quickbird image, the vegetation seems to be quite homogenous throughout this whole area.

Just west of this vineyard another major environmental alteration is indicated by the multi-temporal data analysis. A big quarry was developed sometime after 1992 but before 1996 when air photographs show its operation at a very early stage. This quarry is located on flysch, mainly consisting of shale and sandstone. Such materials are widely used in local housing settlements for decorative reasons. The quarry works have expanded, gradually causing a decrease in the forest vegetation that used to cover 
the surrounding area. Restoration of the quarry site must have begun between 2003 and 2005 because there is no blue in the false color image at this location, indicating that the reflectance was not that of bare soil when the latest Landsat image was acquired (Figure 4). There is also a smoothing of the relief as shown in the Quickbird image; this is not consistent with the exposure of the steep quarry terraces that are clearly visible in the 1996 high resolution air photographs.

Figure 4. Multi-temporal pseudo-color image produced from layer stacking of Landsat satellite data (Band 3, 0.63 to $0.69 \mu \mathrm{m}$ ) with three different acquisition dates. High contrast spots in the forested area reveal changes in reflectance due to human activity or forest fires. The time at which the reflectance changed can be estimated by the colors on the image, as described in the text (see black arrows).

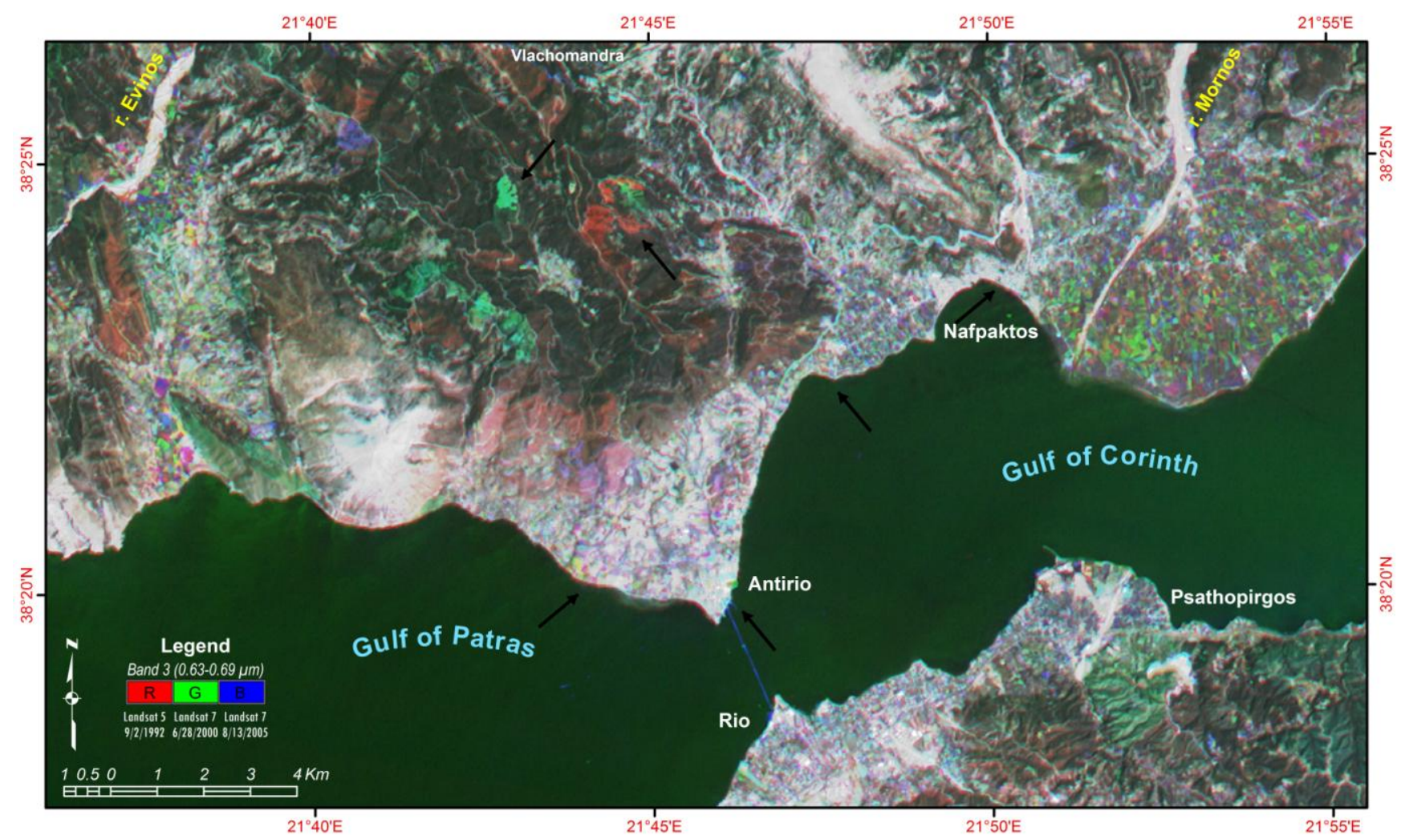

For many years now, the reduction in water flow along rivers emptying into the Gulf of Corinth has caused coastal erosion and a regression of the shoreline. This could be related to construction of several dams along upstream portions of the rivers or perhaps to global climate change. Multi-temporal interpretation of Landsat images reveals that the northern coastlines of the two gulfs, on either side of Antirio, have suffered serious regression. In the near infrared datasets a discontinuous red stripe of a few pixels width is visible, beginning just east of Nafpaktos through the west of its waterfront, indicating that the beach which existed there in 1992 - and possibly for many years before-has eroded (Figures 4,5). 
Figure 5. Multi-temporal pseudo-color image produced from layer stacking of Landsat satellite data (Band 4, 0.76 to $0.90 \mu \mathrm{m}$ ) with three different acquisition dates. The high absorbance of water creates a high reflectance contrast along the coastline so that shoreline regression is easily observed and quantified. The white arrows point to alterations of the coastal areas described in the text.

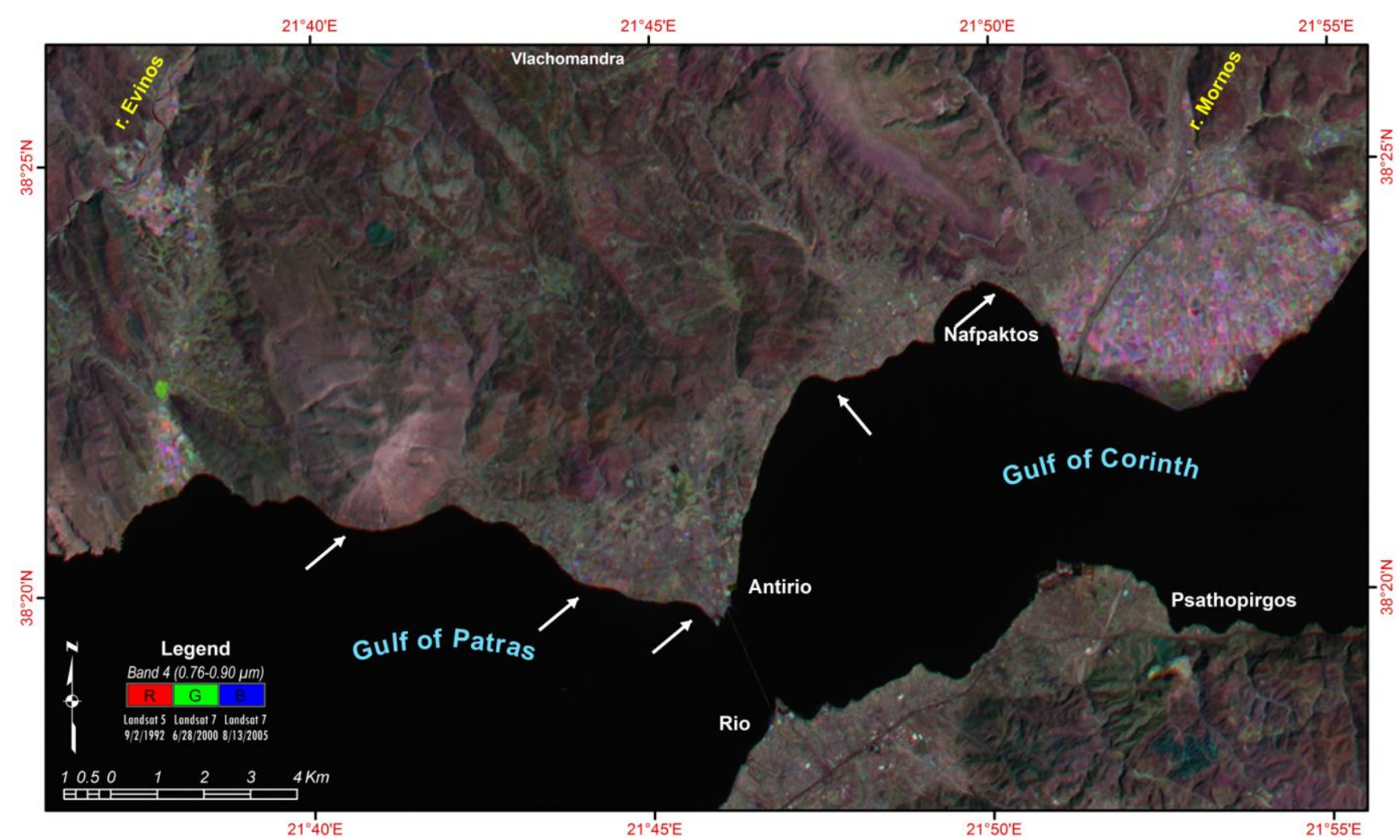

Along the eastern coast of the Antirio fan, no significant changes in the shoreline can be observed. A blue linear feature corresponds to a small pier constructed before 2005 but after 2000. In contrast, along the western part of the coastal deltaic area, an almost continuous red stripe corresponds to a regression of the 1992 shoreline, which in places has regressed by as much as 50 meters. Reddish pixels can also be observed along the western part of the coastline in the study area, where the main outcrops onshore consist of limestone, conglomerate, shale and sandstone, which make up parts of the flysch sequence. The steep topographic slopes present here, combined with the high frequency of planes of weakness in the rock (caused by bedding, joints, etc.) have the potential to produce rock fall into the sea; thus the red pixels along the coast line might represent missing land surfaces destroyed by rock fall, with rock fall probably occurring after 2000 and definitely after 1992. The epicenter of the large Aigion earthquake on June 15, 1995 ( $M=6.1)$ is located just $35 \mathrm{~km}$ eastward of this area, suggesting that rock fall could have been triggered directly by the earthquake or be related to post seismic surface deformation [20].

The Evinos dam, which is not located in the study area, has apparently altered the natural flow regime of the river. This has created temporary changes in the pattern of river incision, especially in the low relief segments of the valley at the northwestern end of the study area. In the multi-temporal pseudo-color images these changes are visible as linear features of different colors and widths; these 
linear features cross each other in a wide part of the river valley (Figure 6). These shifts in the river bed and incision pattern could have been the result of short-term meteorological changes, but because the three multi-temporal images were all acquired during the summer it is most likely that they are caused by controlled water release at the Evinos dam. Controlled water release at the dam would produce a significant change in the rate of discharge and sediment carrying capacity in downstream portions of the river, potentially causing erosion, landsliding and/or rock fall in the lithological formations that outcrop adjacent to the river valley, especially after sudden flooding.

Similar phenomena do not seem to have occurred along the Mornos river valley, perhaps because this dam has been in operation since 1981 and did not alter its operations during the period when the satellite images were acquired, or because a narrow artificial watercourse was constructed downstream of the dam in order to avoid floods at the river outlet in the Mornos deltaic fan area.

Figure 6. Multi-temporal pseudo-color image produced from layer stacking of Landsat satellite data (Band 5, 1.55 to $1.75 \mu \mathrm{m}$ ) with three different acquisition dates. The pattern of water flow in the rivers has shifted throughout the thirteen year observation period as indicated by crosscutting linear features of different colors. The black arrows point to alterations of the surface described in the text.

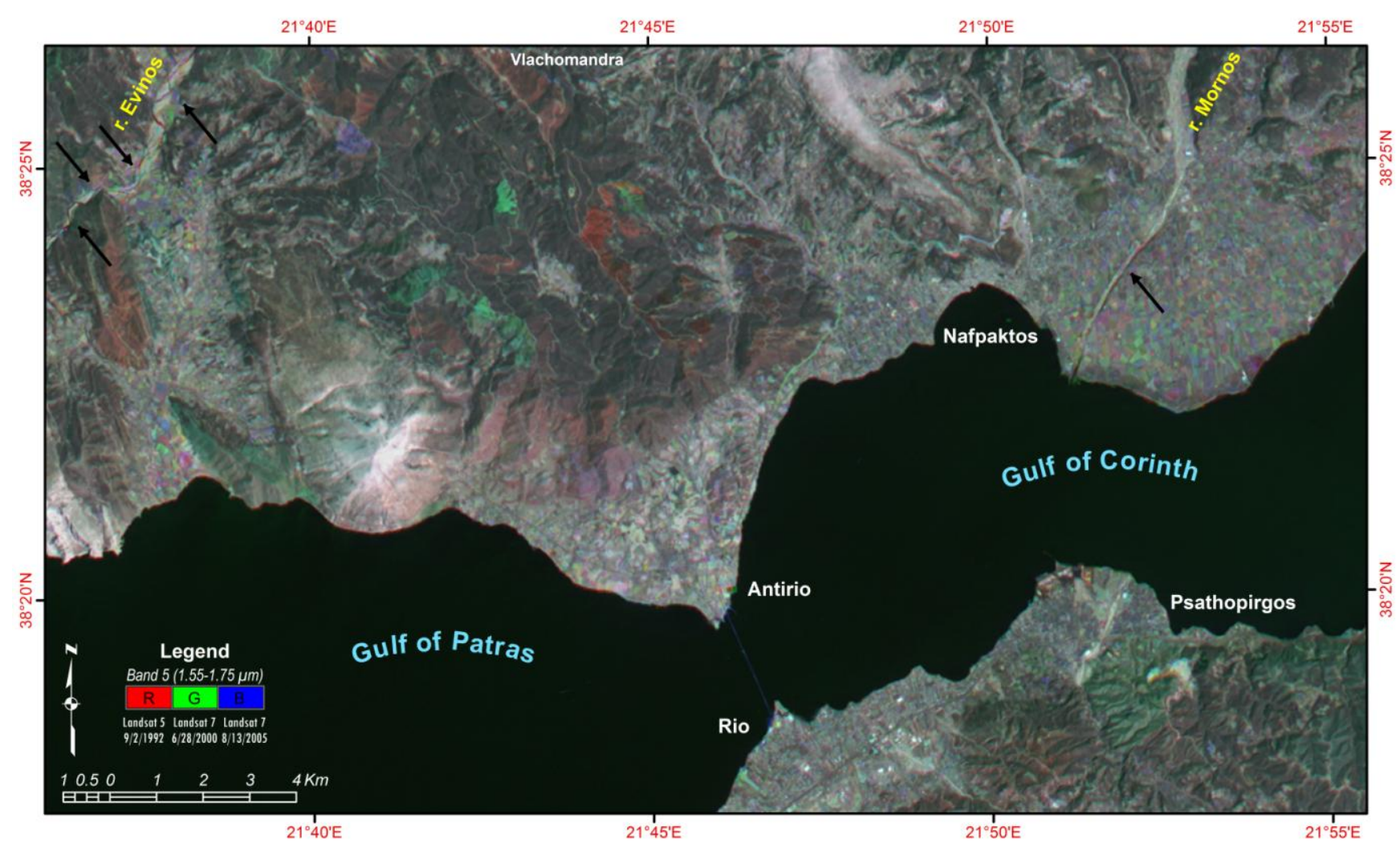

Because the lithology of the mountainous area consists mainly of flysch [21] and the climate is generally humid, the forest is extremely dense. During the summer whilst temperatures are high, forest fires occur quite frequently, resulting in large burnt areas with consequent environmental effects. By using the multi-temporal interpretation technique of Landsat data images, the areas affected by forest fires can by highlighted and one might be able to determine the extent of the burned area and the 
approximate time of the fire. In the case of Antirio, several burnt areas are apparent on the image in Figure 7.

A bluish area just east of the Evinos river valley corresponds to a burnt area that appeared between 2000 and 2005; there has been no effective rehabilitation. There are also many spotty areas in the forests that display a mixture of colors; these are in contrast with the densely vegetated areas that were burned and subsequently restored between the three capturing dates. For a more detailed study in terms of time, a more complete time series of images should be used in the future by applying the same methodology but with shorter periods of time between the capturing dates of the acquired remote sensing data.

Figure 7. Multi-temporal pseudo-color image produced from layer stacking of Landsat satellite data (Band 7, 2.08 to $2.35 \mu \mathrm{m}$ ) with three different acquisition dates. The reflectance in this band highlights the difference between bare soil and cultivated land, thus showing areas that have been denuded by forest fires. The various colors show surface changes between the three satellite acquisition dates. In particular, large areas of a reddish color appear across the mountainous area where previously burnt areas have been rehabilitated either naturally or artificially before the 2000 Landsat data was acquired. The black arrows point to alterations of the surface described in the text.

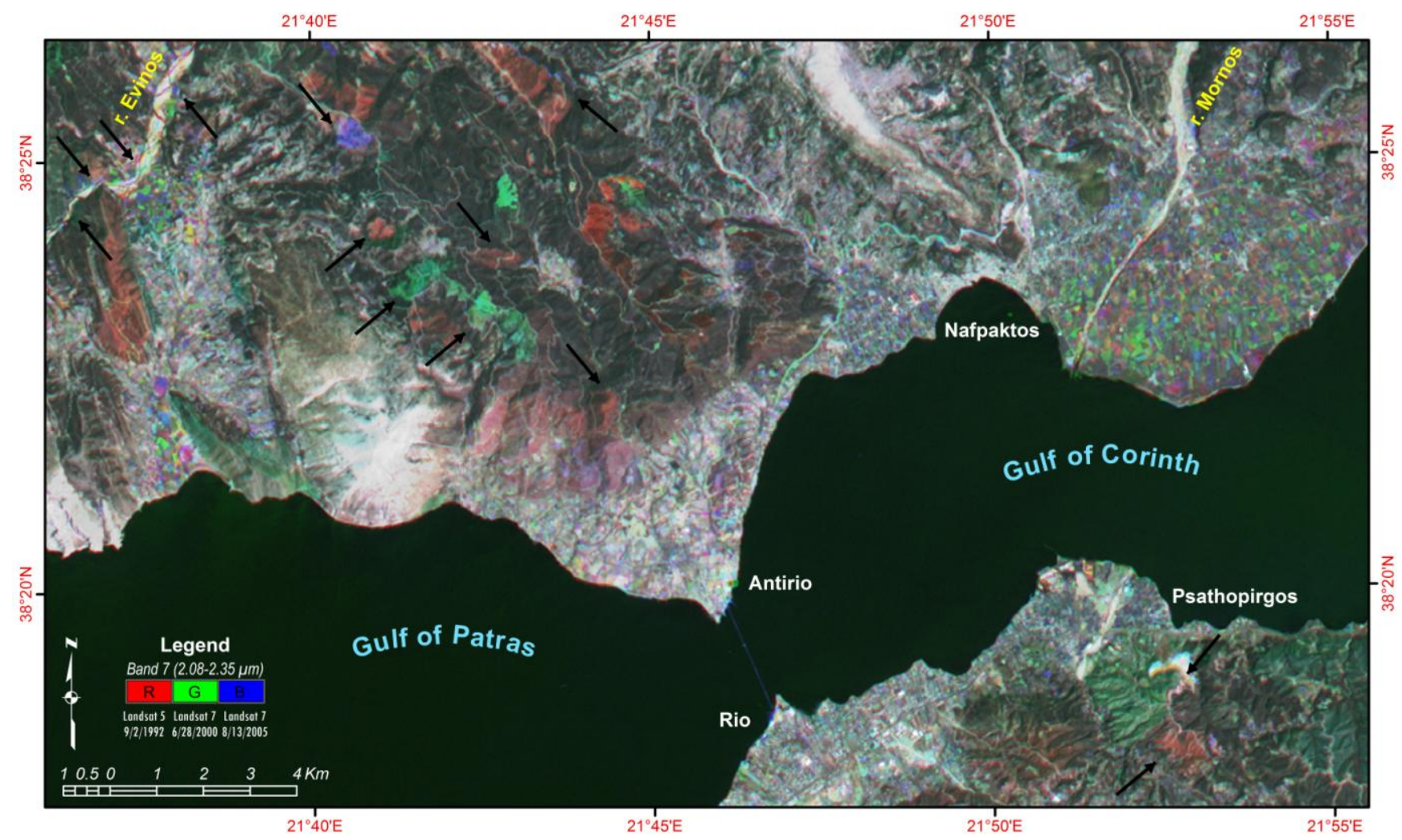

\section{Conclusions}

For the last decade, Greece has been making an ongoing investment in its infrastructure in western mainland Greece, including the building of roads, bridges and dams. The human interaction with the natural landscape evolution has a much higher impact than if the human factor was less significant. 
Almost all the landscape evolution observed for this area is directly or indirectly connected to major ongoing construction activities.

The environmental impact of these activities would not be apparent without the interpretation of remote sensing data such as described in this paper. The region of western Greece is nearly ideal for applying techniques involving multi-temporal remote sensing data because in a very short time period many environmental alterations have occurred due to natural and human activities. The multi-temporal image interpretation technique allows for the identification and, in many cases, the quantification of these environmental effects. The availability of a dense time series of remote sensing multispectral data provides an opportunity to identify changes on the earth's surface. In some cases, these may signal major environmental changes of a serious nature and indicate the need for preventative measures to avoid an environmental disaster.

This paper highlights the important role that analysis of multispectral satellite data can play in the identification of surface alterations related to human activity and natural processes. In some cases high resolution satellite images will also be needed to quantify the spatial extent of surface alterations, but multispectral data, at either medium or high spatial resolution, will remain the key in identifying the existence and timing of changes to the earth's surface environment.

\section{Acknowledgements}

The author would like to thank L. H. Royden for her constructive comments on an early version of this manuscript, as well as two anonymous reviewers whose suggestions and comments highly improved the text and the figure settings. Special thanks are due to D. J. Papanikolaou for encouraging the publication of this study and E. L. Lekkas for kindly offering the Quickbird raw data.

\section{References and Notes}

1. Jackson, J.A.; Gagnepain, J.; Houseman, G.; King, G.; Papadimitriou, P.; Soufleris, C.; Virieux, J. Seismicity, normal faulting, and the geomorphological development of the Gulf of Corinth (Greece) the Corinth earthquakes of February and March 1981. Earth Planet. Sci. Lett. 1982, 57, 377-397.

2. Bernard, P.; Briole, P.; Meyer, B.; Lyon-Caen, H.; Gomez, J.-M.; Tiberi, C.; Berge, C.; Cattin, R.; Hatzfeld, D.; Lachet, C.; Lebrun, B.; Deschamps, A.; Courboulex, F.; Larroque, C.; Rigo, A.; Massonnet, D.; Papadimitriou, P.; Kassaras, J.; Diagourtas, D.; Makropoulos, K.; Veis, G.; Papazisi, E.; Mitsakaki, C.; Karakostas, V.; Papadimitriou, E.; Papanastassiou, D.; Chouliaras, M.; Stavrakakis, G. The $M_{s}=6.2$, June 15, 1995 Aigion earthquake (Greece): evidence for low angle normal faulting in the Corinth rift. J. Seismol. 1997, 1, 131-150.

3. Evangelidis, C.P.; Konstantinou, K.I.; Melis, N.S.; Charalambakis, M.; Stavrakakis, G.N. Waveform Relocation and Focal Mechanism Analysis of an Earthquake Swarm in Trichonis Lake, Western Greece. Bull. Seismol. Soc. Amer. 2008, 98, 804-811.

4. Gaki-Papanastassiou, K.; Papanastassiou, D.; Maroukian, H. Geomorphic and archaeologicalhistorical evidence for past earthquakes in Greece. Ann. Geofis. 1996, 39, 589-601. 
5. Papanikolaou, D.; Chronis, G.; Lykousis, V.; Pavlakis, P. Active Tectonics in the Rion-Antirion Strait, Western Greece. In Proceedings of 5th Meeting European Geological Societies, Dubrovnik, Croatia, October 6-7, 1987; pp. 72-73.

6. Briole, P.; Rigo, A.; Lyon-Caen, H.; Ruegg, J.C.; Papazissi, K.; Mitsakaki, C.; Balodimou, A.; Veis, G.; Hatzfeld, D.; Deschamps, A. Active deformation of the Corinth rift, Greece: Results from repeated Global Positioning System surveys between 1990 and 1995. J. Geophys. Res. 2000, 105, 25605-25625.

7. Avallone, A.; Briole, P.; Agatza-Balodimou, A.M.; Billiris, H.; Charade, O.; Mitsakaki, C.; Nercessian, A.; Papazissi, K.; Paradissis, D.; Veis, G. Analysis of eleven years of deformation measured by GPS in the Corinth Rift Laboratory area. Comptes Rendus Geosciences 2004, 336, 301-311.

8. Bernard, P.; Lyon-Caen, H.; Briole, P.; Deschamps, A.; Boudin, F.; Makropoulos, K.; Papadimitriou, P.; Lemeille, F.; Patau, G.; Billiris, H.; Paradissis, D.; Papazissi, K.; CastarOde, H.; Charade, O.; Nercessian, A.; Avallone, A.; Pacchiani, F.; Zahradnik, J.; Sacks, S.; Linde, A. Seismicity, deformation and seismic hazard in the western rift of Corinth: New insights from the Corinth Rift Laboratory (CRL). Tectonophysics 2006, 426, 7-30.

9. Cianetti, S.; Tinti, E.; Giunchi, C.; Cocco, M. Modelling deformation rates in the western Gulf of Corinth: rheological constraints. Geophys. J. Int. 2008, 174, 749-757.

10. Parcharidis, I.; Foumelis, M.; Kourkouli, P.; Wegmuller, U. Persistent Scatterers InSAR to detect ground deformation over Rio-Antirio area (Western Greece) for the period 1992-2000. J. Appl. Geophys. 2009, 68, 348-355.

11. Zelilidis, A. The geometry of fan-deltas and related turbidites in narrow linear basins. Geol. $J$. 2003, 38, 31-46.

12. Bell, R.E.; McNeill, L.C.; Bull, J.M.; Henstock, T.J. Evolution of the offshore western Gulf of Corinth. Geol. Soc. Amer. Bullet. 2008, 120, 156-178.

13. Welch, R.; Ehlers, W. Merging Multiresolution SPOT HRV and Landsat TM Data. Photogramm. Eng. Remote Sensing 1987, 53, 301-303.

14. Rigol, J.; Chica-Olmo, M. Merging remote-sensing images for geological-environmental mapping: application to the Cabo de Gata-Nvjar Natural Park, Spain. Environ. Geol. 1998, 34, 194-202.

15. Pouncey, R.; Swanson, K.; Hart, K. ERDAS Field Guide, 5th ed.; ERDAS Inc: Atlanta, GA, USA, 1999; p. 671.

16. Cracknell, A.; Hayes, L. Introduction to Remote Sensing; Taylor and Francis: London, UK, 1991; p. 293.

17. Mather, P. Computer Processing of Remotely-Sensed Images: An Introduction; Wiley \& Sons: West Sussex, UK, 1994; p. 352.

18. Hadjimitsis, D.G.; Clayton, C.R.I.; Hope, V.S. An assessment of the effectiveness of atmospheric correction algorithms through the remote sensing of some reservoirs. Int. J. Remote Sens. 2004, $25,3651-3674$.

19. Lillesand, T.; Kiefer, R. Remote Sensing and Image Interpretation, 3th ed.; Wiley \& Sons: New York, NY, USA, 1994; p. 750. 
20. Parcharidis, I.; Metaxas, C.; Vassilakis, E. Earth observation data and geographical information system (GIS) techniques for earthquake risk assessment in the western Gulf of Corinth, Greece. Canad. J. Remote Sens. 2006, 32, 223-227.

21. Jenkins, D. Structural development of Western Greece. AAPG Bull. 1972, 56, 128-149.

(C) 2010 by the authors; licensee MDPI, Basel, Switzerland. This article is an open access article distributed under the terms and conditions of the Creative Commons Attribution license (http://creativecommons.org/licenses/by/3.0/). 
Copyright of Remote Sensing is the property of MDPI Publishing and its content may not be copied or emailed to multiple sites or posted to a listserv without the copyright holder's express written permission. However, users may print, download, or email articles for individual use. 